\title{
Friction and Wear Behaviour of 42CrMo4 Steel Treated by Tenifer, Hard Chrome and Plasma Nitriding Technologies
}

\author{
Thanh Van Doan ${ }^{1}$, David Kusmič ${ }^{1}$, Miroslav Pospíchal ${ }^{1}$, Quang Dung Tran², Van Thuan Nguyen ${ }^{2}$ \\ ${ }^{1}$ University of Defence in Brno, Kounicova 65, Brno 662 00. Email: thanhvan.doan@unob.cz, david.kusmic@unob.cz, \\ miroslav.pospichal@unob.cz \\ ${ }^{2}$ Academy of Military Technology, Hoang Quoc Viet 236, Hanoi, Vietnam. Email: quangdung.tran@gmail.com, thuan- \\ vatlieu@gmail.com
}

Concerning with effort to replace hard chrome plating cause of its ecological issues, this paper investigates the effects of surface technologies to wear resistance of ISO $42 \mathrm{CrMo4}$ steel, which is popularly used in weapon production. After quenching and tempering, the experimental samples were treated by nitrocarburizing (tenifer), hard chrome plating and plasma nitriding technologies. Plasma nitriding was carried out with different gas mixture at $500^{\circ} \mathrm{C}$ (plasma nitriding process) for $15 \mathrm{~h}$. The wear test based on principle "pin on disc" was performed to evaluate the coefficient of friction and the wear rate. The results were supplemented with surface hardness test and metallografical evaluation. The experiment results point out that nitrocarburizing and plasma nitriding improve wear resistance better than hard chrome plating.

Keywords: nitrocarburizing, hard chrome plating, plasma nitriding, pin on disc, wear resistance

\section{Acknowledgements}

The paper has been prepared thanks to the support of the project The Development of Technologies, Design of Firearms, Ammunition, Instrumentation, Engineering of Materials and Military Infrastructure "VÝZBROJ (DZRO K201)" and "Surface technology in applications special techniques SV16-216".

\section{References}

[1] FIŠER, M., BALLA, J. (2004). Small arms weapon, U-1377, Brno 2004.

[2] PYE, D. (2003). Practical nitriding and ferritic nitrocarburizing. 2nd edition, In: ASM International Materials, Park 2003, p. 66-68.

[3] DOBROCKY, D., KUSMIC D. (2015). The effect of plasma nitriding process on the change of dynamic parameters of steeel DIN 1654/4. In: Manufacturing technology, Vol. 15 (3), p. 14-20. ISSN 1213-2489.

[4] HOLEMAR, A., HRUBY, V. (1989). Iontová nitridace v praxi. 1. vyd. Státní nakladatelství technické literatury, Praha. ISBN 80-03-00001-7.

[5] POKORNY, Z., HRUBÝ, V. and STUDENÝ, Z (2016). Effect of nitrogen on surface morphology of layers. In: Metallic Materials 54, 119-12.

[6] POKORNÝ, Z., HRUBÝ, V. (2011). Plasma Nitriding of Deep Narrow Cavities", In: Key Engineering Materials, Vol. 465, p. 267-270.

[7] Chrome plating: A guide for selecting the type of chrome plating for use in contact with Bal Seal spring-energized seals in rotary and reciprocating serivice. In: http://www.balseal.com [online]. [cit. 2016-08-24]. Available from: http://www.balseal.com/sites/default/files/TR-14_revision_G.pdf

[8] DOAN, T. V.; KUSMIČ, D.; POSPÍCHAL, M. (2015). Surface Treatment Technologies for Wear Resistance Increasing of 42CrMo4 Steel. In: Manufacturing Technology, vol. 15, no. 3, p. 303-307. ISSN 1213-2489.

[9] Glock advantage. Http://eu.glock.com/ [online]. [cit. 2016-08-24]. Available from: http://eu.glock.com/english/index_pistols.htm

[10] NIKOLUSSI, M. et al. (2007). Examination of phase transformations in the system Fe-N-C by means of nitrocarburising reactions and secondary annealing experiments the $\alpha+\varepsilon$ two phase equilibrium. Material Research. 2007, 98, s. 1086-1092. ISSN 1862-5282.

[11] DIN 50190-2 Hardness depth of heat-treated parts; determination of the effectivedepth of hardening after flame or induction hardening. Deutches Institut Für Normung E. V. (German National Standard), 1979, 4 s.

[12] ASTM G99-95, Standard Test Method for Wear Testing with a Pin-on-Disk Apparatus, ASTM International, West Conshohocken, PA, 2000, www.astm.org. 
[13] RABINOWICZ, E. (1995). Friction and wear of materials. Canada: John Wiley \& Sons, Inc. ISBN 0-471-830844.

[14] PELAGIĆ, Z., NÁGEL', M., ŽMINDÁK, M., RIECKY, D. (2015). Wear Simulation Modeling by Using the Finite Element Method. In: Manufacturing technology, Vol. 15 (2), p. 191-195. ISSN 1213-2489.

[15] KUSMIC, D., DOBROCKY, D. (2015). Corrosion Resistance of Plasma Nitrided Structural Steels. In: Manufacturing technology, Vol. 15 (1), p. 64-69. ISSN 1213-2489.

\section{Paper number: M201732}

Copyright (C) 2017. Published by Manufacturing Technology. All rights reserved. 